\title{
Residues of some Toxic Heavy Metals and Trace Elements in Chicken Eggs
}

\author{
Walaa F. Saad Eldin* and Amal A. Raslan \\ Educational Veterinary Hospital, Faculty of Veterinary Medicine, Zagazig University, 44511, \\ Egypt \\ Article History: Received: 15/12/2017 Received in revised form: 17/1/2018 Accepted: 28/1/2018
}

\begin{abstract}
Presence of residues of heavy metals and trace elements in chicken eggs represent chemical hazards from the point of view of both Food safety sector due to consumption of contaminated eggs and poultry medicine sector due to the possible harmful effects of metals on chicken embryos, embryonic deaths, in particular. The objective of this study was to estimate the residual concentrations of the toxic metals (lead, cadmium, arsenic and nickel) and trace elements (zinc and copper) in three kinds of chicken eggs. The examined chicken eggs included balady (produced from free-range house fed chickens), commercial eggs, produced from laying hens fed on commercial ration and organic eggs produced from laying hens fed on organic based ration. A total of 60 fresh egg samples were collected randomly from (20, each) during the period from June to October 2016 Sharkia Governorate, Egypt. The achieved results declared that balady chicken eggs had the highest load of all metals examined followed by commercial and finally organic eggs. The residual concentrations of all examined metals exceeded the maximum permissible limits set by Food and Agricultural Organization (FAO)/ World Health Organization (WHO), especially in the balady $\{\mathrm{Pb}(0.34 \pm 0.03)$; $\mathrm{Cd}(0.18 \pm 0.02)$; As $(0.14 \pm 0.017)$; $\mathrm{Zn}$ $(23.17 \pm 0.88)$; $\mathrm{Ni}(1.31 \pm 0.08)$, and $\mathrm{Cu}(11.47 \pm 0.66)\}$, followed by commercial then organic eggs. High metal concentrations in chicken eggs represent major hazards on both human and chicken embryos that might lead to sever toxicological implications. The adverse outcomes of the examined metals on both human and chicken embryos were discussed.
\end{abstract}

Keywords: Heavy Metals, Trace Elements, Chicken Eggs.

\section{Introduction}

Eggs as a food matrix represent a major source of animal-derived protein, minerals and vitamins. Eggs, especially produced by freerange chicken are considered ideal samples for monitoring environmental pollutants because chickens live under the same environment as humans [1]. Heavy metals and trace elements are found in the environment as a result of geochemical changes or due to anthropogenic activities. Some of the trace elements are needed to certain limit by living organisms to maintain normal body functions such as zinc $(\mathrm{Zn})$ and copper $(\mathrm{Cu})$. Non-essential elements such as lead $(\mathrm{Pb})$, cadmium $(\mathrm{Cd})$, arsenic (As) and nickel $(\mathrm{Ni})$ have well-documented toxic effects. Monitoring of such contaminants is a matter of importance for risk assessment of both animals and humans [2].

Chickens, either free-range or under intensive rearing systems, are exposed to vast array of heavy metals and trace elements via inhalation of polluted air or ingestion of contaminated feed. Poultry feed contains high concentrations of minerals which is directly added to the ration to fulfill the bird body requirements and in many cases, exceed the bird needs. Additionally, poultry ration in many cases contain bone or fish meals, which are considered major sources of feed contamination with metals. Some of these metals can cross the egg shell and even represent a risk factor for the chicken embryos [3]. Estimation of metal concentrations in chicken eggs is an important subject, which is related to food safety, poultry medicine and an environmental alarming issue. This study was undertaken to estimate the concentrations of four toxic metals (lead, cadmium, arsenic and nickel) and two trace elements (zinc and copper) in balady, commercial and organic chicken eggs and compare these concentrations with the standard national permissible limits. 


\section{Materials and Methods}

\section{Collection of samples}

A total of 60 fresh egg samples were collected randomly from balady, commercial and organic eggs (20, each). Balady egg samples were collected from free-range chickens (house-fed) at villages of Sharkia Governorate, Egypt, during the period from June to October 2016. Commercial eggs were collected from laying hens' farms (depend on commercial layers' ration), while organic eggs were produced from laying hens fed on organic based rations.

\section{Sample preparation and extraction}

Heavy-metal levels in the examined eggs were measured according to Wet digestion method [4]. In summary, egg white and yolk were mixed and homogenized together. Samples were firstly dried at $70^{\circ} \mathrm{C}$ to get constant weight. Then, one gram of each sample was mixed with $10 \mathrm{~mL} 3: 2 \mathrm{HNO}_{3}$ $(65 \% \mathrm{v} / \mathrm{v}): \mathrm{HC}_{1} \mathrm{O}_{4}(70 \% \mathrm{v} / \mathrm{v})$. The mixture was digested for $5 \mathrm{~h}$ in water bath at $70^{\circ} \mathrm{C}$ with swirling at $30 \mathrm{~min}$ intervals to ensure complete digestion. After cooling, the digest was transferred into $15 \mathrm{~mL}$ falcon tubes and stored at room temperature until metal analyses.

\section{Measurement of heavy metal concentrations}

All reagents were analytical grade and standard solutions of $\mathrm{Zn}, \mathrm{Cu}, \mathrm{Pb}, \mathrm{Cd}$, As and

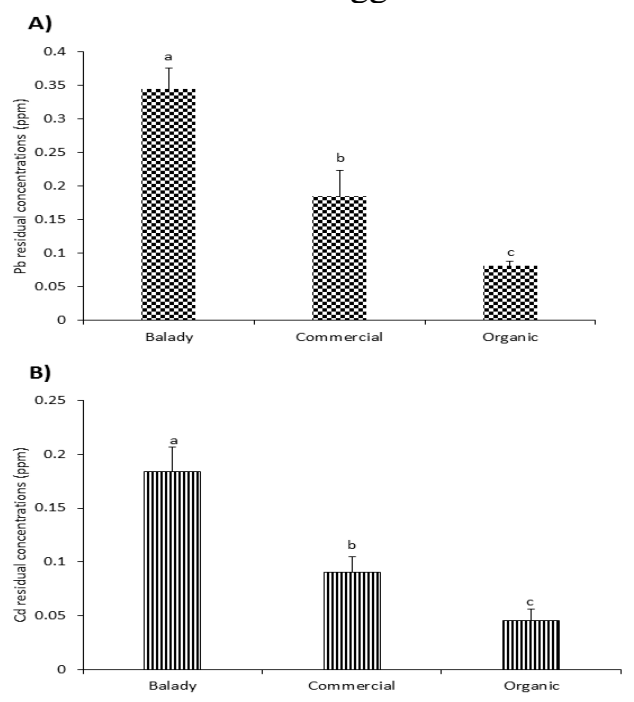

Figure 1: Lead and cadmium residual concentrations in chicken egg; A) Lead (Pb); B) Cadmium (Cd). The results were recorded as mean $\pm \mathrm{SE}$ ( $\mathrm{ppm} /$ wet weight) of $\mathrm{Pb}$ and $\mathrm{Cd}$ concentrations in chicken egg ( $\mathrm{n}=20 \mathrm{each}$ of balady, commercial and organic eggs). Means carrying different small letter are statistically significant among the examined chicken egg type. $(\mathrm{P}<0.05)$.

Lead (Pb)
Ni were purchased from Merck, Darmstadat, Germany. Metal concentrations were directly measured by using an atomic absorption spectrophotometer (PerkinElmer 2380), using hollow cathode lamps, equipped with airacetylene flame. Mean recoveries for all metals ranged from 95 to $105 \%$. The detection limits (ppm) were $0.05(\mathrm{~Pb}), 0.005(\mathrm{Cd})$, $0.02(\mathrm{As}), 0.01(\mathrm{Ni}) 0.1(\mathrm{Zn})$, and $0.05(\mathrm{Cu})$, respectively. Samples and blank solutions were measured in triplicates.

\section{Statistical analysis}

Statistical significance was evaluated using Tukey-Kramer honestly significant difference tests, with $p<0.05$ considered as significant (JMP program, SAS Institute, Cary, NC, USA) [5].

\section{Results and Discussion}

Estimation of heavy metals in eggs gives an indication about chicken exposure to metals during their lifetime. Chicken exposure to heavy metals and trace elements is due to ingestion of repeated small doses of such chemicals via feed and water. These metals can pass to the egg representing a risk factor for both chicken embryos in hatching eggs and humans who consume contaminated table eggs. In this study, we estimated the concentration of toxic metals $(\mathrm{Pb}, \mathrm{Cd}$, As and $\mathrm{Ni})$ and trace elements $(\mathrm{Zn}$ and $\mathrm{Cu})$ in whole egg. 
Balady eggs had significantly $(\mathrm{P}<0.05)$ the highest $\mathrm{Pb}$ concentrations followed by commercial and organic eggs. The mean $\pm \mathrm{SE}$ values of $\mathrm{Pb}$ concentrations in the examined egg samples were $0.34 \pm 0.03,0.18 \pm 0.04$ and $0.08 \pm 0.007 \mathrm{ppm}$ in balady, commercial and organic eggs, respectively (Figure 1A). The recorded concentrations in this study were comparable with $\mathrm{Pb}$ concentrations found in chicken eggs in Egypt (Giza) and Bangladesh [6,7]. However, higher $\mathrm{Pb}$ concentration $(0.42$ ppm) was reported in Malaysia [8].

Lead concentrations recorded in this study exceeded $\mathrm{FAO} / \mathrm{WHO}$ [9] recommended concentration $(0.1 \mathrm{ppm})$ in $85 \%, 30 \%$ and $10 \%$ of the examined balady, commercial and organic eggs, respectively (Figure 4). Excess lead in food can cause serious damage to the brain, kidneys, nervous system and red blood cells in humans [10]. Food poisoning due to lead intoxication is recently reported in children in Nigeria, Zambia and China [1113]. When lead finds the way to the chicken body, it accumulates in the bone, egg (shell, yolk and albumen), soft tissues such as liver and kidneys and leads to elevated blood lead levels [14]. The recorded concentrations of $\mathrm{Pb}$ residues in the egg in this study is very close to the toxic concentrations of $\mathrm{Pb}(1 \mathrm{ppm})$ that lead to $\mathrm{Pb}$ intoxication in chicken. When chicken receive such concentrations of $\mathrm{Pb}$ in their diet, signs of depression, poor growth rate and food conversion ratio occur. Acute lead poisoning in chickens may develop muscle weakness, ataxia, and loss of appetite, followed by marked weight loss, eventual cessation of egg production and severe anemia may develop. Young chickens are more susceptible than adult chickens. Chronic $\mathrm{Pb}$ toxicity in chicken leads to severe muscle atrophy, degeneration of neurons and lower immune response [15].

A)

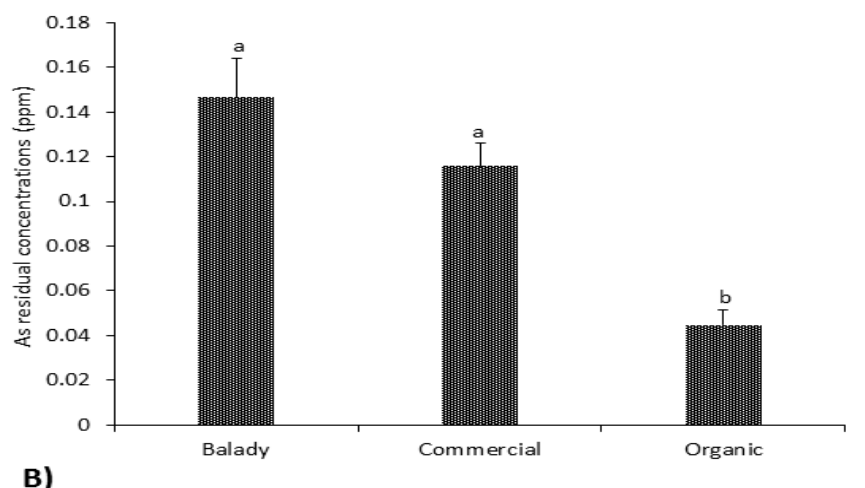

B)

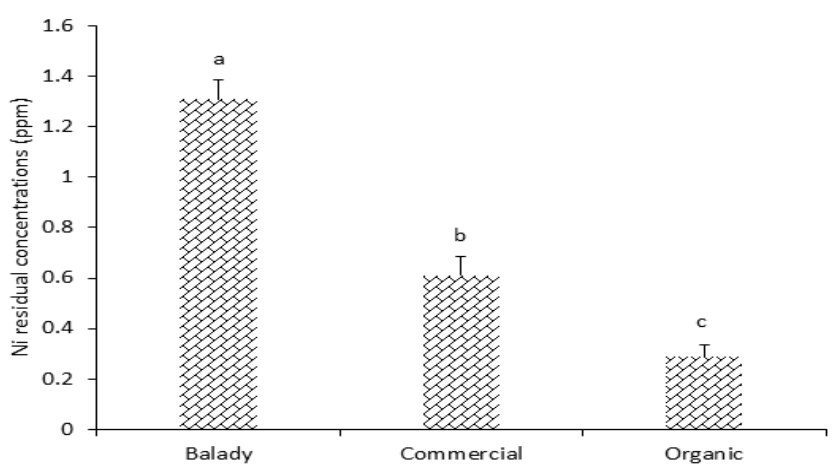

Figure 2: Arsenic and nickel residual concentrations in chicken egg; A) Arsenic (As); B) Nickel (Ni). The results were recorded as mean $\pm \mathrm{SE}(\mathrm{ppm} /$ wet weight) of As and Ni concentrations in chicken egg ( $\mathrm{n}=20 \mathrm{each}$ of balady, commercial and organic eggs). Means carrying different small letter are statistically significant among the examined chicken egg type. $(P<0.05)$. 


\section{Cadmium (Cd)}

Cadmium contamination of environment and food chain is usually due to the abuse of $\mathrm{Cd}$ in industry of batteries, pigments and stabilizers. In this study, the mean $\mathrm{Cd}$ concentrations recorded in the examined egg samples were $0.18 \pm 0.02,0.09 \pm 0.01$ and $0.04 \pm 0.01 \mathrm{ppm}$ in balady, commercial and organic eggs, respectively. Similar to $\mathrm{Pb}, \mathrm{Cd}$ concentrations were significantly higher in balady eggs followed by commercial and organic eggs (Figure 1B). The recorded concentrations in this study are in agreement with the previous reports in Malaysia and Egypt $[6,8]$. Unlikely, higher $\mathrm{Cd}$ concentration (0.3 ppm) was recorded in Bangladesh [7]. Nisianakiset al. [16] recorded lower $\mathrm{Cd}$ concentrations $(1.44 \pm 0.138 \mathrm{ppb})$ in chicken eggs marketed in Greece.
Comparing the obtained concentrations in this study with the allowed Maximum Permissible Limits (MPL) of $\mathrm{Cd}$ in eggs decided by FAO/WHO (0.1 ppm), it is clear that $40 \%$ and $20 \%$ of the examined balady and commercial eggs exceeded that limit (Figure 4). Cadmium is known by it's severe toxicity and long-term exposure to $\mathrm{Cd}$ is associated with kidney malfunction, mutations, cancers and embryonic deaths [17]. The outbreak of Itai-Itai disease in Cd-polluted areas in Japan is an evidence for the toxic effects of $\mathrm{Cd}$ on the bones. The major symptoms of Itai-Itai disease patients include severe osteomalacia accompanied with multiple bone fractures and renal dysfunction [18]. In chicken, Cadmium is reported to cause thyroid dysfunction with concomitant increase of lipid peroxidation in chicken after oral exposure to $2.5 \mathrm{mg} / \mathrm{kg}$ daily for 15 days [19].

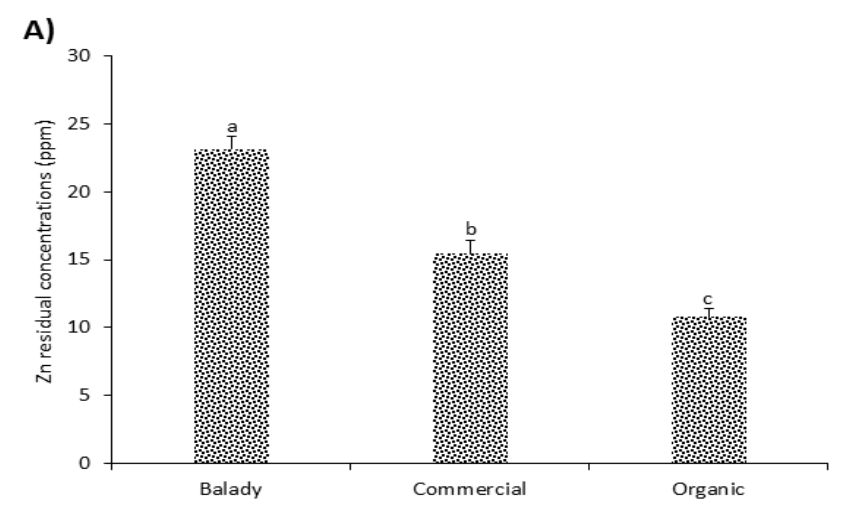

B)

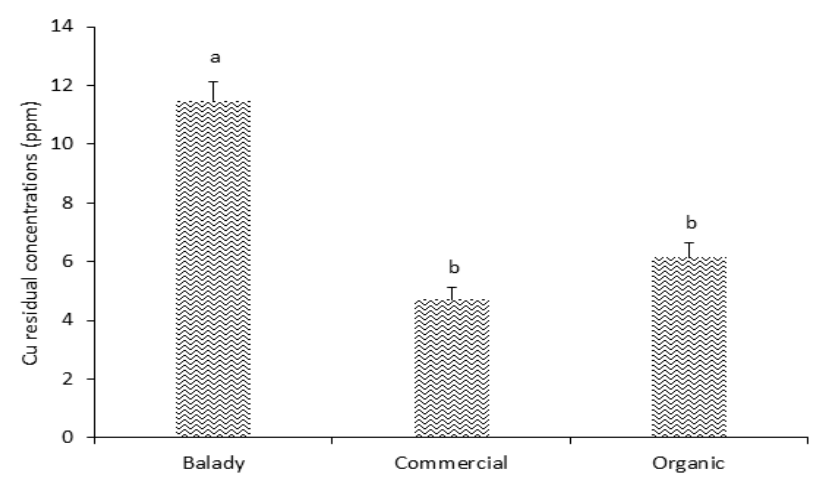

Figure 3: Zinc and Copper residual concentrations in chicken egg; A) Zinc (Zn); B) Copper (Cu). The results were recorded as mean $\pm \mathrm{SE}$ ( $\mathrm{ppm} /$ wet weight) of $\mathrm{Zn}$ and $\mathrm{Cu}$ concentrations in chicken egg (n=20 each of balady, commercial and organic eggs). Means carrying different small letter are statistically significant among the examined chicken egg type. $(\mathrm{P}<0.05)$. 


\section{Arsenic (As)}

Chicken receives several arsenical compounds supplied normally to the ration for the control of diseases and improvement of the body gain and feed conversion ratio. These arsenical compounds are mostly excreted unchanged in chicken litter and subsequently may contaminate the produced eggs [20]. The results recorded in Figure $2 \mathrm{~A}$ showed the mean residual concentrations of As (ppm) in the examined chicken egg samples. Balady and commercial eggs had significantly higher mean concentrations of As $(0.14 \pm 0.017$ and $0.12 \pm 0.01)$ compared with organic eggs $(0.04$ $\pm 0.006)$. The recorded concentrations of As in commercial eggs in this study are in agreement with that reported in Greece [16]. Higher concentrations of As were recorded in chicken eggs marketed in Malaysia $(0.3 \mathrm{ppm})$ and Bangladesh (0.3 ppm) [7,8]. Lower values were reported in commercial eggs marketed in Giza, Egypt (0.033 ppm) [6]. Twenty-five percentage of balady eggs (Figure 4) exceeded MPL of As (0.1 ppm) established by FAO/WHO [9].

Acute or subacute arsenic exposure might induce gastrointestinal disturbances ranging from mild abdominal cramping and diarrhea to severe life-threatening hemorrhagic gastroenteritis associated with shock. Chronic exposure to arsenic is related to skin lesions, cancers, cardiovascular effects, diabetes, pulmonary malfunction, neurological symptoms, and developmental and reproductive toxicity [21]. Arsenic effects in chicken were investigated after dietary exposure of chicken to elevated concentrations of arsenic trioxide $(7.5-30 \mathrm{mg} / \mathrm{kg})$. Arsenic triggered chicken defense and produced nervous disorders represented by induction of the expression of inflammatory-related genes in the cerebrum, cerebellum, thalamus, brain stem and myelencephalon [22].

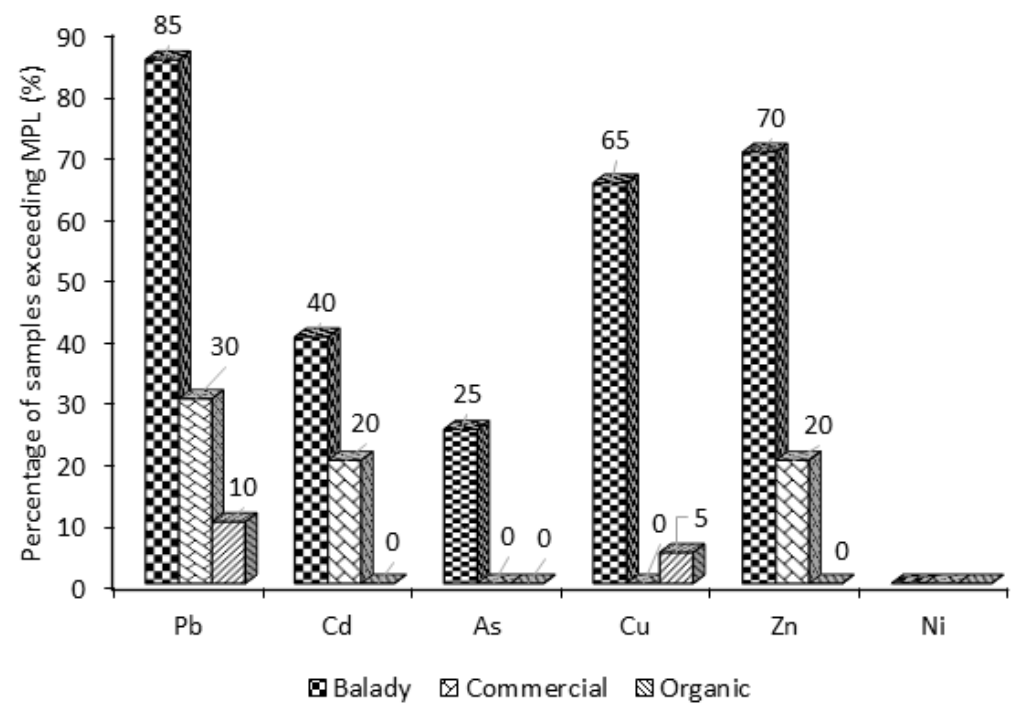

Figure 4: Percentage of chicken egg samples exceeding maximum permissible limits of heavy metals and trace elements under study.

\section{Nickel (Ni)}

Nickel concentrations analysis in this study was recorded in Figure 2B. Balady eggs were significantly the highest in the Ni load (ppm) $(1.31 \pm 0.08)$, followed by commercial eggs $(0.61 \pm 0.74)$ and organic eggs $(0.29 \pm 0.05)$.
Results of Nickel concentrations in this study were corresponding to that recorded in Malaysia (1.11 ppm) and Bangladesh (1.35 ppm) $[7,8]$.

There is no report about MPL of nickel (Figure 4). Nickel is a metal of no known 
biological function in humans and animals. However, dietary exposure to nickel compounds is associated with dermatitis and cancer risk in humans [23]. The activity of liver enzymes was increased by dietary supplementation of $500 \mathrm{mg} \mathrm{Ni} / \mathrm{kg}$, indicating damage of the liver parenchyma. The results of serum biochemistry were confirmed by a mild or moderate form of pathological focal fatty infiltration of the liver in broilers [24].

\section{Zinc (Zn)}

The obtained results in Figure 3A showed the mean concentrations of $\mathrm{Zn}$ in the examined samples.

It is clear from this figure that balady eggs had significantly the highest $\mathrm{Zn}$ concentrations followed by commercial eggs and finally eggs produced on organic base. The mean $\pm \mathrm{SE}$ residual concentrations of $\mathrm{Zn}(\mathrm{ppm})$ in the examined samples were $23.17 \pm 0.88,15.42 \pm$ 1.03 and $10.77 \pm 0.59$ in the examined balady, commercial and organic eggs, respectively. The reported $\mathrm{Zn}$ concentrations in this study were corresponding to that reported in chicken eggs $(15.75 \pm 4.05 \mathrm{ppm})$ collected from Campania region in Southern Italy [25]. Unlikely, higher $\mathrm{Zn}$ concentrations were reported in upper Egypt (56.8 \pm 2.89 ppm) [6]; lower $\mathrm{Zn}$ concentrations were reported in chicken eggs produced in Peshawar, Pakistan [3].

Comparing the obtained $\mathrm{Zn}$ concentrations in chicken eggs from this study with MPLs established by FAO/WHO [9] revealed that all the examined organic eggs were within the allowed Zn MPL (20 ppm), however $70 \%$ and $20 \%$ of the examined balady and commercial eggs exceeded this limit (Figure 4). Zinc is one of the essential trace elements that is needed for the normal body functions. It is essential for the function of many enzymes and receptors in the body. Furthermore, $\mathrm{Zn}$ has a documented antioxidant and antiinflammatory effects and promote the immune system in animals and humans [26]. However, the role of dietary $\mathrm{Zn}$ supplementation in increasing the body gain or the feed conversion efficiency is not clear. For instance, chickens fed on diets supplemented with $\mathrm{Zn}(600 \mathrm{mg} / \mathrm{kg})$ had a slightly lower body weight, compared with those given 0 or 300 $\mathrm{mg} / \mathrm{kg}$ of Zn. Nevertheless, this body weight decrease did not affect meat yield [27].

\section{Copper $(\mathrm{Cu})$}

Copper residual concentrations were also estimated in this study. Similar to Zn, balady eggs had significantly $(\mathrm{p}<0.05)$ the highest $\mathrm{Cu}$ residual concentration followed by both of organic and commercial eggs. The recorded $\mathrm{Cu}$ residues $(\mathrm{ppm})$ in the examined samples were $11.47 \pm 0.66,4.17 \pm 0.42$ and $6.15 \pm 0.51$ in balady, commercial and organic eggs, respectively (Figure 3B). The obtained concentrations of $\mathrm{Cu}$ in this study were in agreement with the previous published reports from Egypt, Pakistan and Bangladesh [3,6,7]. Unlikely, lower residual $\mathrm{Cu}$ concentrations were recorded in chicken eggs from Greece and Italy [16,25].

The recorded $\mathrm{Cu}$ concentrations in this study exceeded MPL (10 ppm) of FAO/WHO (JECFA, 2005) [9] in $65 \%$ and $5 \%$ of the examined balady and organic eggs, respectively (Figure 4).

Copper is one of the essential trace elements that is needed as a cofactor for various enzymes such as cytochrome oxidase and superoxide dismutase, $\mathrm{Cu}$ is also an essential element for cellular respiration and free radical defense. Exposure to excess concentrations of $\mathrm{Cu}$ lead to oxidative damage to single macromolecules such as lipoproteins, DNA, or thiol containing enzymes [28]. In the poultry industry, copper sulfate is added in a concentration of 125 to $250 \mathrm{ppm}$ to poultry rations in the United States as a growth promoter. However, the exact mechanisms behind this growth promotion activity are not clear. One of the possible mechanisms could be attributed to the bactericidal, bacteriostatic, or both, effects of $\mathrm{Cu}$ on the gastrointestinal tract (GIT) microbiota [29].

From all obtained results in this study, it notes worthy that different kinds of chicken eggs had different metal accumulation pattern, which might be attributed to bird-strain differences that might subsequently affect metal detoxification pathways.

\section{Conclusion}

It is clear that chicken eggs represent a major source of both human and chicken 
embryo exposure to various metals and trace elements, which might represent a potential hazard leading to various biological consequences. Thus, we highly recommend continuous screening of metal load in eggs produced by different avian species as well as ration introduced to birds, which represent the major source of chicken exposure to these metals.

\section{Conflict of interest}

The authors declare that there is no conflict of interest.

\section{References}

[1] Giannenas, I.; Nisianakis, P.; Gavriil, A.; Kontopidis, G. and Kyriazakis, I. (2009): Trace mineral content of conventional, organic and courtyard eggs analysed by inductively coupled plasma mass spectrometry (ICP-MS). Food Chem, 114(2): 706-711.

[2] Darwish, W.S.; Hussein, M.A.; El-Desoky, K.I.; Ikenaka, Y.; Nakayama, S.; Mizukawa, H. and Ishizuka, M. (2015): Incidence and public health risk assessment of toxic metal residues (cadmium and lead) in Egyptian cattle and sheep meats. Int Food Res J, 22(4): 17191726.

[3] Islam, M.S.; Zafar, M. and Ahmed, M. (2014): Determination of heavy metals from table poultry eggs in PeshawarPakistan. J Pharmacogn Phytochem, 3(3): 64-67.

[4] Finerty, M.W.; Madden, D.; Feagly, E. and Orodner, M. (1990): Effect of environment and seasonality on metal residues in tissues of wild and pondraised cray fish in southern Louisiana. Arch Environ. Contam. Toxicol, 19(1): 94-99.

[5] Gomez, K.A. and Gomez, A.A. (1984): Statistical procedures for agriculture research. John Wiliy and Sons Editor I nc. USA(2Ed.), Chapter 3:129-184.

[6] Hashish, S.M.; Abdel-Samee, L.D. and Abdel-Wahhab, M.A. (2012): Mineral and heavy metals content in eggs of local hens at different geographic areas in Egypt. Global Vet, 8(3): 298-304.
[7] Shaheen, N.; Ahmed, M.K.; Islam, M.S.; Habibullah-Al-Mamun, M.; Tukun, A.B.; Islam, S.M.A. and Rahim, A.T. (2016): Health risk assessment of trace elements viadietary intake of 'non-piscine protein source' foodstuffs (meat, milk and egg) in Bangladesh. Environ Sci Pollut Res Int, 23(8): 7794-806.

[8] Abduljaleel, S.A. and Shuhaimi-Othman, M. (2011): Health risk from eggs consumption. J Biol Sci, 11(7):448-453.

[9] JECFA (2005): Codex general standard for contaminants and toxins in food and feeds. In: 64th meeting of the Joint FAO/WHO Expert Committee on Food Additives (JECFA), JECFA/64/CAC/RCP 49-2001.

[10] Darwish, W.S. and Ikenaka, Y. (2013): Biological responses of xenobiotic metabolizing enzymes to lead exposure in cultured H4IIE rat cells. Jpn J Vet Res, 61: S48-S53.

[11] Ajumobi, O.O.; Tsofo, A.; Yango, M.; Aworh, M.K.; Anagbogu, I.N.; Mohammed, A.; Umar-Tsafe, N.; Mohammed, S.; Abdullahi, M.; Davis, L. and Idris, S (2014): High concentration of blood lead levels among young children in Bagega community, Zamfara - Nigeria and the potential risk factor. Pan Afr Med J, 18: 1-14.

[12] Xu, J.; Sheng, L.; Yan, Z. and Hong, L. (2014): Blood Lead and Cadmium Levels of Children: A Case Study in Changchun, Jilin Province, China. West Indian Med J, 63(1): 29-33.

[13] Yabe, J.; Nakayama, S.M.; Ikenaka, Y.; Yohannes, Y.B.; Bortey-Sam, N.; Oroszlany, B.; Muzandu, K.; Choongo, K.; Kabalo, A.N.; Ntapisha, J. and Mweene, A. (2014): Lead poisoning in children from townships in the vicinity of a lead zinc mine in Kabwe, Zambia. Chemosphere, 119C: 941-947.

[14]Youssef, S.A.; El-Sanousi, A.A.; Afifi, N.A. and El-Brawy, A.M. (1996): Effect of subclinical lead toxicity on the immune response of chickens to Newcastle disease virus vaccine. Res Vet Sci, 60(1): 13-16. 
[15]Trampel, W.D.; Imerman, M.P.; Carson, L.T.; Kinker, A.J. and Ensley, M.S. (2003): Lead contamination of chicken eggs and tissues from a small farm flock. J Vet Diagn Invest,15(5):418-422.

[16] Nisianakis, P.; Giannenas, I.; Gavriil, A.; Kontopidis, G. and Kyriazakis, I. (2009): Variation in trace element contents among chicken, turkey, duck, goose, and pigeon eggs analyzed by inductively coupled plasma mass spectrometry (ICP-MS). Biol Trace Elem Res, 128(1): 62-71.

[17] Pitot, H.C. and Dragan, P. (1995): The instability of tumor promotion in relation to human cancer risk. Prog Clin Biol Res, 391: 21-38.

[18] Bernard, A. (2008): Cadmium \& its adverse effects on human health. Indian $\mathbf{J}$ Med Res, 128(4):557-64.

[19] Gupta, P. and Kar, A. (1999): Cadmium induced thyroid dysfunction in chicken: hepatic type I iodothyronine 5'monodeiodinase activity and role of lipid peroxidation. Comp Biochem Physiol C Pharmacol Toxicol Endocrinol, 123(1):39-44.

[20] Christen, K. (2001): Chickens, manure, and arsenic. Environ Sci Technol, 35(9):184A-185A.

[21] Feng, H.; Gao, Y.; Zhao, L.; Wei, Y.; Li, Y. and Wei, W. (2013): Biomarkers of renal toxicity caused by exposure to arsenic in drinking water. Environ. Toxicol Pharmacol, 35: 495-501.

[22] Sun, X.; He, Y.; Guo, Y.; Li, S.; Zhao, H.; Wang, Y.; Zhang, J. and Xing, M. (2017): Arsenic affects inflammatory cytokine expression in Gallus gallus brain tissues. BMC Vet Res, 13(1):157.

[23] Cempel, M. and Nikel, G. (2006): Nickel: a review of its sources and environmental toxicology. Pol J Environ Stud, 15(3): 375-382.

[24] Bersényi, A.; Fekete, S.G.; Szilágyi, M.; Berta, E.; Zöldág, L. and Glávits, R. (2004): Effects of nickel supply on the fattening performance and several biochemical parameters of broiler chickens and rabbits. Acta Vet Hung, 52(2):185-97.

[25] Esposito, M.; Cavallo, S.; Chiaravalle, E.; Miedico, O.; Pellicanò, R.; Rosato, G.; Sarnelli, P. and Baldi, L. (2016): Trace elements in free-range hen eggs in the Campania region (Italy) analyzed by inductively coupled plasma mass spectrometry (ICP-MS). Environ Monit Assess, 188(6): 326.

[26] Zhang, L.; Wang, J.S.; Wang, Q.; Li, K.X.; Guo, T.Y.; Xiao, X.; Wang, Y. X. and Zhan, X.A. (2017): Effects of Maternal Zinc Glycine on Mortality, Zinc Concentration, and Antioxidant Status in a Developing Embryo and 1Day-Old Chick. Biol Trace Elem Res, 181(2):323-330. [27] Bou, R.; Guardiola, F.; Barroeta, A.C. and Codony, R. (2005): Effect of dietary fat sources and zinc and selenium supplements on the composition and consumer acceptability of chicken meat. Poult Sci, 84(7):112940 .

[28] Darwish, W.S.; Ikenaka, Y.; Nakayama, S. and Ishizuka, M. (2014): The effect of copper on the mRNA expression profile of xenobiotic-metabolizing enzymes in cultured rat H4-II-E cells. Biol Trace Elem Res, 158(2): 243-248.

[29] Pang, Y. and Applegate, T.J. (2007): Effects of dietary copper supplementation and copper source on digesta $\mathrm{pH}$, calcium, zinc, and copper complex size in the gastrointestinal tract of the broiler chicken. Poult Sci, 86(3):531-537. 


$$
\begin{aligned}
& \text { الملخص العربي } \\
& \text { بقايا بعض المعادن الثقيلة السامة والعناصر النادرة في بيض الاجاج } \\
& \text { و لاء فتحي سعد الدين ، أمل رسلان عبد العزيز } \\
& \text { المستشفى البيطري التعليمي ـ كلية الطب البيطري - جامعة الزقازيق - } 011 \text { ـ ؛ مصر }
\end{aligned}
$$

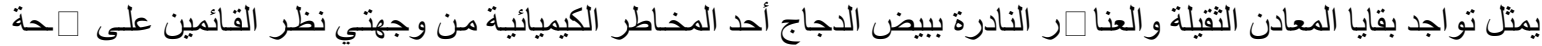

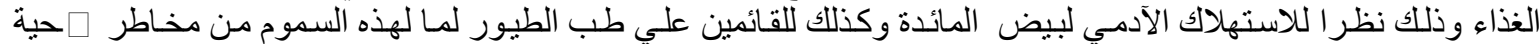

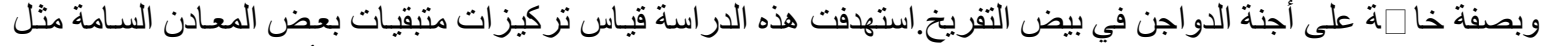

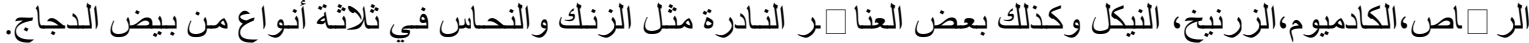

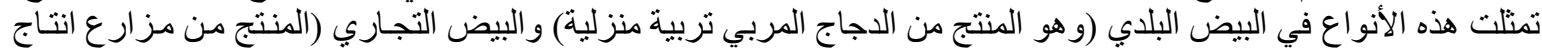

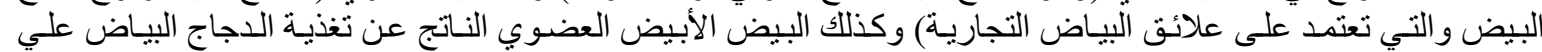

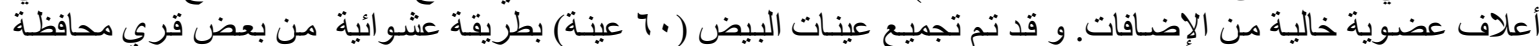

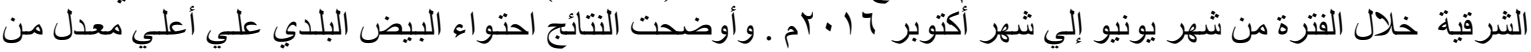

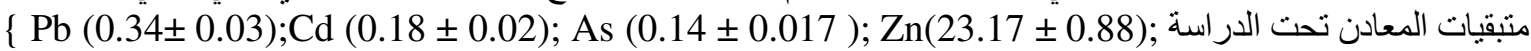

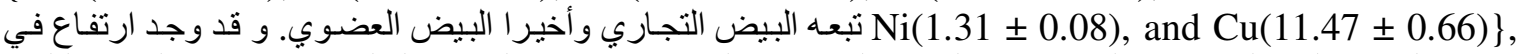

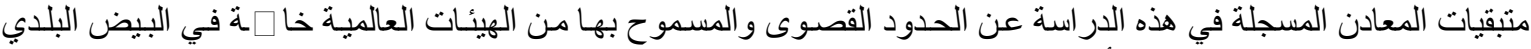

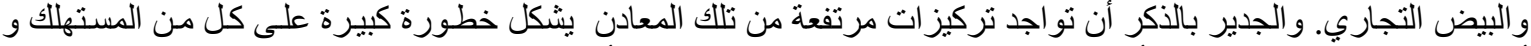

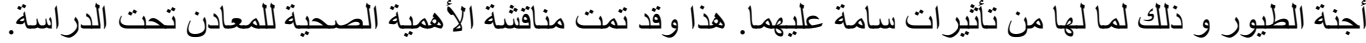

